\title{
New geological insights and structural control on fluid circulation in La Fossa cone (Vulcano, Aeolian Islands, Italy)
}

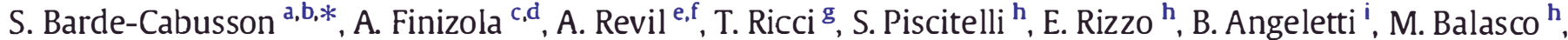 \\ L. Bennati ${ }^{j}$, S. Byrdina ${ }^{\text {b,k }}$, N. Carzaniga ${ }^{\text {I }}$, A. Crespy ${ }^{i}$, F. Di Gangi ${ }^{d}$, J. Morin ${ }^{\mathrm{c}, \mathrm{m}}$, A. Perrone ${ }^{\mathrm{h}}$, M. Rossi ${ }^{\mathrm{n}, \mathrm{l}}$, \\ E. Roulleau ${ }^{\circ}$, B. Suski ${ }^{\text {p.i }}$, N. Villeneuve ${ }^{q}$ \\ a Dipartimento di Saienze della Terra, Università Degli Studi di Firenze, Italy \\ ' LMV, Université Blaise Pascal, Clennont-Ferrand, France \\ c Laboratoire CéoSciences Réunion, UR, IPCP, UMR 7154, Saint-Denis, La Réunion, France \\ "Istituto Nazionale di Geofsica e Vulcanologia, Palermo, Italy \\ e Colorado School of Mines, Dept. of Geophysics, Golden, CO, USA \\ f ONRS-LGIT (UMR 5559), University of Savie, Equipe Volcan, Chambéry, France \\ g Istitu to Nazionale di Geofisica e Vulcanologia, Roma, Italy \\ h IMAA-ONR, Laboratory of Geophysics Tito Scalo (PZ), Italy \\ ' CNRS-GREGE, Université Paul Cézanne, Aix en Provence, France \\ j Dept. of Earth \& Atmospheric Sciences, Purdue University, West Lafayette, USA \\ k Equipe de Céomagnétisme, IPCP, UMR 7154, 4, Place Jussieu, 75005 Paris, France \\ ' Università Milano-Bicocca, Milan, Italy \\ m Université Paris 1, Panthéon-Sorbonne, Paris, France \\ " Dipartimento di Geosaienze, Università di Padova, Italy \\ - GEOTOP-UQAM-MCGill, Montréal, Canada \\ P Université de Lausanne (UNIL), Institut de Géophysique, Lausanne, Switzerland \\ ${ }^{a}$ Institut de Recherche pour le Développement, US 140 ESPAC, La Réunion, France
}

Electric resistivity tomography (ERT), self-potential (SP), soil $\mathrm{CO}_{2}$ flux and temperature are used to study the inner structure of $\mathrm{La}$ Fossa cone (Vulcano, Aeolian Islands). Nine profiles were performed across the cone with a measurement spacing of $20 \mathrm{~m}$. The crater rims of La Fossa cone are underlined by sharp horizontal resistivity contrasts. $\mathrm{SP}, \mathrm{CO}_{2}$ flux, and temperature anomalies underline these boundaries which we interpret as structural limits associated to preferential circulation of fluids. The Pietre Cotte crater and Gran Gratere crater enclose the main hydrothermal system, identified at the centre of the edifice on the base of low electrical resistivity values $(<20 \Omega \mathrm{m})$ and strong $\mathrm{CO}_{2}$ degassing, SP, and temperature anomalies. In the periphery, the hydrothermal activity is also visible along structural boundaries such as the Punte Nere, Forgia Vecchia, and Palizzl crater rims and at the base of the cone, on the southern side of the edifice, along a fault attributed to the NW main tectonic trend of the island. Inside the Punte Nere crater, the ERTsections show an electrical resistive body that we interpret as an Intrusion or a dome. This magmatic body is reconstructed in 3D using the available ERT profiles. Its shape and position, with respect to the Pietre Cotte crater fault, allows replacing this structure in the chronology of the development of the volcano. It corresponds to a late phase of activity of the Punte Nere edifice. Considering the position of the SP, soll $\mathrm{CO}_{2}$ flux, and temperature maxima and the repartition of conductive zones related to hydrothermal circulation with respect to the main structural features, La Fossa cone could be considered as a relevant example of the strong influence of pre-exi sting structures on hydrothermal fluid circulation at the scale of a volcanic edifice.

\footnotetext{
* Corresponding author. Dipartimento di Scienze della Terra, Università di Firenze, Via Giorgio La Pira 4, 50121, Firenze, Italy. Tel.: +39055 2757479; fax: +39055 2756242.

E-mail address: s.barde.cabusson@gmail.com (S. Barde-Cabusson).
}

\section{Introduction}

Active volcanoes are not only the place of magma transfers but also of permanent heat and fluid transfers from the magma reservoir to the surface, even during long periods of eruptive quiescence. These exchanges are mainly insured by convective circulations of hot ground fluids (gas and liquids) inside the hydrothermal system (e.g., Aubert and Baubron, 1988; Granieri et al., 2006; Finizola et al., 2003, 2006). 
A volcanic edifice can be a very heterogeneous structure due to its eruptive dynamics and evolution. It is usually shaped by an alternation of lava flow units, ash layers, volcanoclastic deposits, clay-rich materials resulting from hydrothermal alteration, various intrusions, all heterogeneously affected by deformation and the presence of cracks. During its evolution, more permeable levels and interfaces develop owing to the superposition of the various geological units. However, structural limits and fracture zones formed inside the volcano along its history can constitute the more permeable zones. These weakness planes allow the infiltration of meteoric waters, the rise of hydrothermal fluids, and sometimes the transfer of magma. A good example is provided by caldera structures, where the hydrothermal activity concentrates along the border fault and on intracalderic fractures (e.g., Pribnow et al., 2003). In a comparative study of the Valles caldera (New Mexico) and of the calderas of Lake City and Platoro (Colorado), Wohletz and Heiken (1992) highlight that the hydrothermal alteration develops principally along the faults formed inside the caldera and around shallow intrusions. Also, the crater boundaries being highly permeable zones of the edifice, they usually guide fluid circulation in the same way (e.g., Revil et al., 2004). In addition to these localized pathways, the transfers can be more pervasive depending on the permeability of the volcanic materials, e.g., the diffuse degassing of $\mathrm{CO}_{2}$ (Baubron et al., 1990; Allard et al., 1991).

The hydrothermal activity can also alter the cohesion of rocks and therefore be responsible for large collapses and landslides or for the spreading of volcanic edifices (López and Williams, 1993; Day, 1996; Vallance and Scott, 1997; Voight and Elsworth, 1997; van Wyk de Vries et al., 2000; Reid et al., 2001; Merle and Lénat, 2003; Cecchi et al., 2005). The hydrothermal alteration, in addition to increasing the risk of instability, also enhances the mobility of the debris avalanches. Indeed, the hydrothermal alteration reduces the cohesion of the rock and increases the fluid content favouring these risks (e.g., Vallance and Scott 1997). On Vulcano, a landslide occurred the 20th April 1988 on the north-eastern flank of La Fossa cone. A volume of $220,000 \mathrm{~m}^{3}$ of superficial pyroclastic deposits was implicated. This destabilization was contemporary of the opening of fractures affected by fumarolic emanations and hydrothermal alteration (Ricci, 2007). Currently, given the strong alteration of the rocks around the Forgia Vecchia (north-north-east flank) this area is of major landslide-probability and, due to the population density, in particular during the tourist season, it presents a major risk. Understanding the relationships between pre-existing structures and fluid circulation is important to study volcanic hydrothermal systems and could help to forecast possible volcanic instabilities in the long term.

Because drilling volcanic edifices is difficult, non-intrusive methods that can image the structure of a volcanic edifice and that can be sensitive to the flow of the ground water and $\mathrm{CO}_{2}$ are important to understand the dynamics of hydrothermal systems. They constitute very important tools to extrapolate the observations made at the ground surface to depth in order to draw a map of the geohazards associated with a volcanic edifice. La Fossa cone (Vulcano, Aeolian Islands, Italy) is a small and complex volcanic edifice characterized by a strong alteration due to a very active hydrothermal system. In addition, we have a good knowledge regarding its eruptive history (De Astis et al., 2007 and references therein). It is therefore an ideal natural laboratory to conduct a high resolution survey investigating the structure and the hydrothermal system of a volcanic edifice.

We acquired multi-electrode electric resistivity data (ERT), selfpotential (SP), soil $\mathrm{CO}_{2}$ diffuse degassing, and shallow ground temperature data along several profiles. The same dataset was used by Revil et al. (2008) to present the main structural features interpreted from some of the profiles and to perform a numerical modelling of the ground water flow pattern. In our case, this multidisciplinary study is used to map the signature of the hydrothermal activity of La Fossa cone and to detail its inner structure above the sea level.
The main goals of this study are (1) to interpret the data in terms of geological features and (2) to understand how pre-existing geological structures control the pattern of fluid circulation.

\section{Geological setting}

Located in the south of Tyrrhenian Basin, Vulcano is the third largest of the seven Aeolian Islands. It is also the southernmost island of the archipelago. Salina, Lipari, and Vulcano are three islands aligned along a NNW-SSE trend, unconformable with respect to the arc layout. This volcanic lineament is explained by a magmatic activity controlled by regional tectonics. Indeed, the development of these islands is strongly influenced by an active crustal discontinuity related to the Tindari-Letojanni dextral strike-slip fault system formed in the continuation of the Malta escarpment (Barberi et al., 1994; Ventura, 1994; Ghisetti, 1979). The horizontal displacements along the strikeslip system are accommodated by N-S to NE-SW trending normal faults and accompanied by pure extension (Mazzuoli et al., 1995).

Vulcano Island was built by a succession of constructive and destructive stages of the two main edifices, Vulcano Primordiale and La Fossa cone (Fig. 1). Vulcano Primordiale is the oldest (120-100 ka, see Keller, 1980). This unit, located in the southern part on the island, is also commonly named Piano or Serro di Punta Lunga. This stratovolcano has been truncated around 100 ka by the collapse of the Piano Caldera, now filled by post-collapse eruptive materials (De Astis et al., 1989). The eruptive centre has then migrated to the north-west to form the Cardo tuff cone and the Lentia intrusive Complex. Both have been largely masked owing to the collapse of La Fossa Caldera and because of the edification of La Fossa cone inside the caldera depression (De Astis et al., 2007).

La Fossa cone is a $391 \mathrm{~m}$ height stratocone, active since $\sim 6000$ years (Dellino and La Volpe, 1997; De Rosa et al., 2004). Its eruptive history and structure have been studied by many authors (e.g., Keller, 1970, 1980; Frazzetta et al., 1983, 1984; Dellino and La Volpe 1997; De Astis et al., 1997, 2003, Arrighi et al., 2006). The present day edifice results from six main phases of activity described in the last issue of the geological map of the island (De Astis et al., 2007) which we simplified in Fig. 1.

(1) Punte Nere formation is composed of pyroclastic products corresponding to surges and fallouts deposits at the base. The upper unit is a succession of aa lava flows. This formation constitutes the former Fossa cone, associated to Punte Nere crater (PN) and now truncated to the west by the younger cone.

(2) Palizzi formation is composed of three units. The first unit show a pyroclastic succession of varicoloured ashes ("Tufi varicolori di La Fossa"). Two younger units display an alternation of pyroclastic deposits and lava flows. In the meantime, a new eruptive centre was active in the northern part of the island, forming the Vulcanello peninsula. The corresponding crater $\operatorname{rim}(\mathrm{Pa})$ is nowadays only visible on the southern part of La Fossa cone.

(3) Caruggi formation, previously named Commenda (Frazzetta et al., 1984; Arrighi et al., 2006) consists of pyroclastic deposits with yellow-reddish ashes and rounded, hydrothermalized lithic blocks. The upper unit corresponds to varicoloured tuffs and ash layers. This layer is well recognized in the landscape as pink coloured outcrops.

(4) Forgia Vecchia formation has settled on the northern flank of La Fossa cone and is made up of lahar deposits. This stage also left an adventive crater (FV), approximately $300 \mathrm{~m}$ wide, on the northern flank.

(5) Pietre Cotte formation consists of a pyroclastic unit mainly visible on the southern flank of La Fossa cone. The cycle is ended by the emission of a striking tongue-like rhyolitic lava flow easily recognisable on the north-west flank. The corresponding crater of Pietre Cotte stage (PC) intersects both PN and Pa craters. 

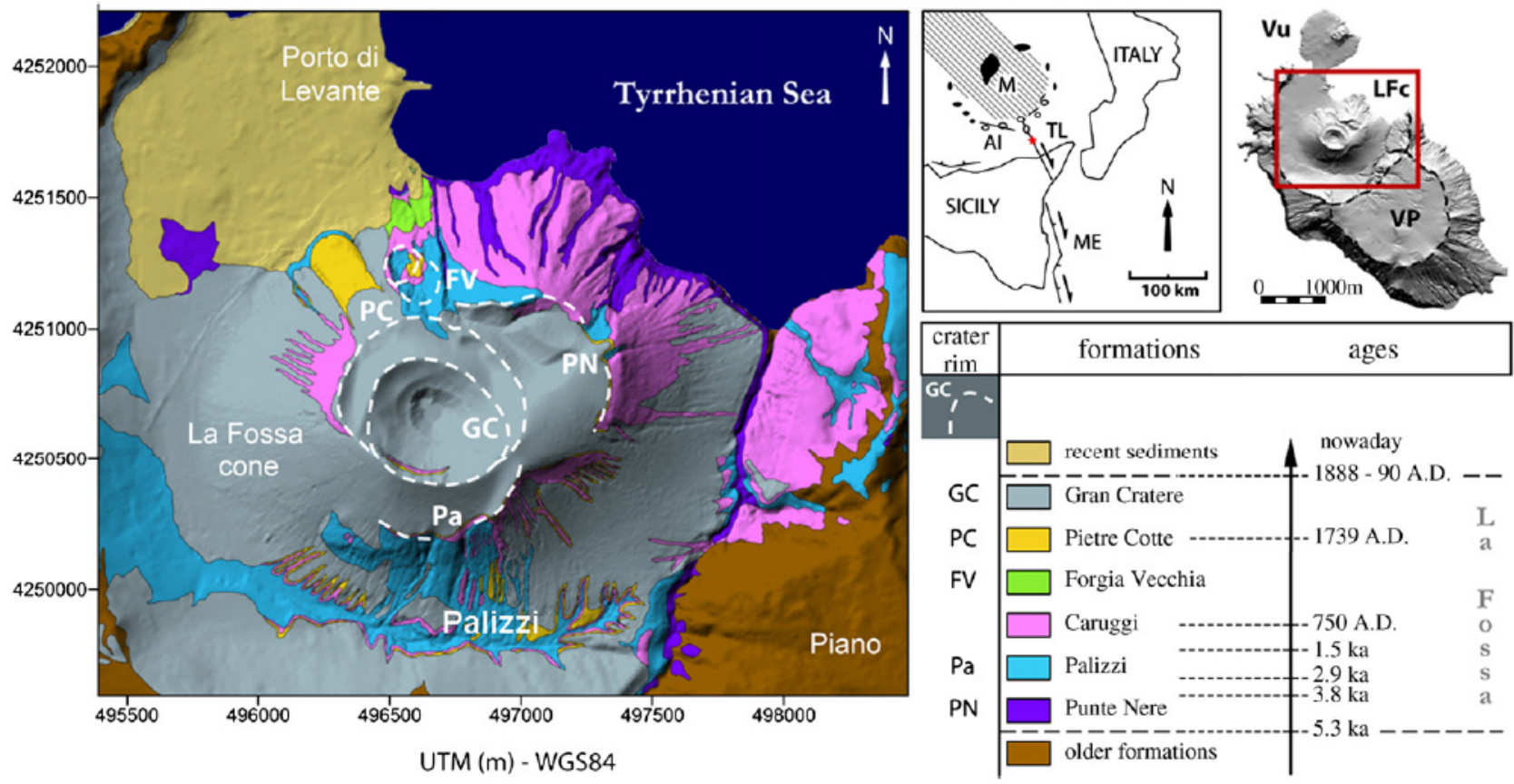

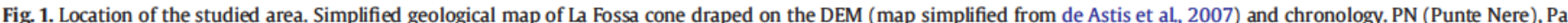

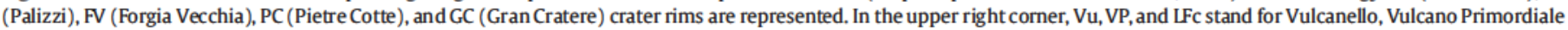

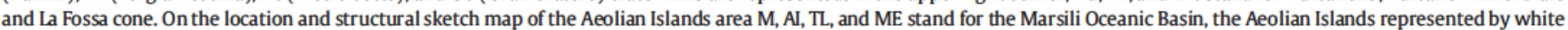

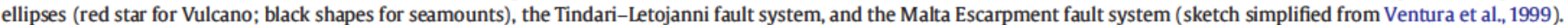

(6) Gran Cratere formation is a pyroclastic level clearly visible on the major part of La Fossa cone as grey ashes. This stage of activity ended with the historical $1888-1890$ eruption and gave rise to the formation of a succession of nested craters (GC) partly overlapping the PC crater rim.

The current activity on Vulcano is characterized by intense fumarolic emissions in La Fossa crater, on the northern and southern flanks of the edifice and in the area of the Porto di Levante harbour. Other isolated fumaroles have been observed on the flanks of the edifice while a strong cold degassing is localized in the Palizzi area. Since 1890 the quiescent La Fossa volcano is characterized by the occurrence of "crises" (Granieri et al., 2006) with strong increases of the fumaroles temperatures and output and variations of the chemical compositions toward more magmatic signatures caused by the uprising of magmatic gas. Moreover, a local anomalous shallow seismicity characterized by swarms of lowmagnitude, due to rising gases in the fumarolic feeding system, an increase of the diffuse soil $\mathrm{CO}_{2}$ degassing, and a spatial expansion of the fumarolic fields are also characteristic of these "crises" but no evidence of magma uprising was signaled.

\section{Data acquisition and processing}

In October 2005, May 2006 and October 2006 we performed three multidisciplinary surveys. Nine profiles were deployed crossing the entire edifice, for a total length of $18,980 \mathrm{~m}$ (Fig. 2). We acquired multielectrode electrical resistivity data with an electrode spacing of $20 \mathrm{~m}$. Self-potential, $\mathrm{CO}_{2}$, and temperature measurements were acquired on the same points, which represent 957 measurements for these methods. The methods used during the surveys are described in detail in Revil et al. (2008). We summarize the main points here.

\subsection{Electric resistivity tomography}

Resistivity measurements were acquired with an ABEM (SAS4000) resistivimeter with a multichannel system of 64 electrodes connected to the acquisition system through a $1260 \mathrm{~m}$ long cable. We used a Wenner array because of its good signal-to-noise ratio. We added salty water around each electrode to decrease the contact resistance between the electrodes and the ground. Two or three roll-alongs were performed to complete each profile. The apparent resistivity values obtained were inverted by RES2DINV software (Geotomo software; Griffiths and Barker, 1993; Loke and Barker, 1996) obtaining a resistivity model along each section. Revil et al. (2008) detailed the inversion process and discussed the results of the tests run to check the uncertainty associated with the resistivity data. The authors conclude that the inverse modelling used is very robust to the noise existing in the raw data. The results allow visualizing a model of resistivity of the edifice. Some of the most representative resistivity models will be presented below as 2D cross-sections.

The interpretation of inverted data alone is a notoriously difficult task because electrical resistivity varies with a number of parameters including temperature, salinity, clay and zeolite contents and mineralogy, grain shape, and porosity (Revil et al., 2002; Rabaute et al., 2003). For the same dataset, there are several possible resistivity models that fit the data equally well (e.g., Auken and Christiansen, 2004; Binley and Kemna, 2005). However, the resistivity models highlight clear spatial resistivity contrasts that can be interpreted in terms of lithology transitions.

\subsection{Self-potential}

SP measurements were performed using a pair of non-polarizing $\mathrm{Cu} / \mathrm{CuSO}_{4}$ electrodes. The difference of electrical potential between the reference electrode (conventionally placed at the beginning of the profile) and the scanning electrode was measured with a calibrated high impedance voltmeter with a sensitivity of $0.1 \mathrm{mV}$. The SP method allows to map rising hydrothermal fluids on active volcanoes; e.g., on Kilauea in Hawaii (Zablocki, 1976), on Nevado de Colima and Fuego de Colima in Mexico (Aubert and Lima, 1986), on Piton de la Fournaise in Reunion Island (Malengreau et al., 1994; Michel and Zlotnicki, 1998), on the Karthala in Comoros (Durand, 1997; Lénat et al., 1998), on 


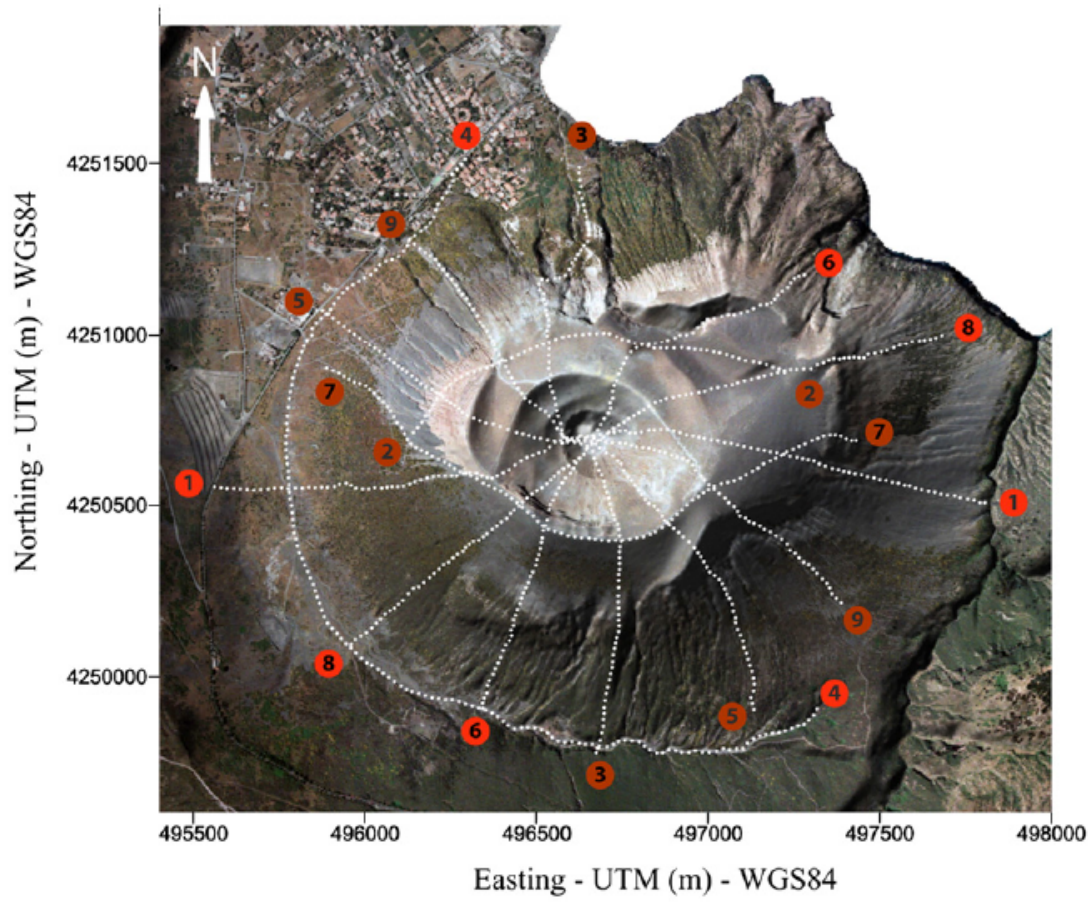

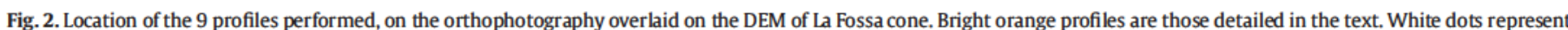

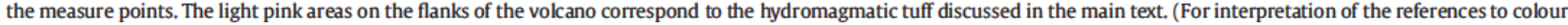
in this figure legend, the reader is referred to the web version of this article.)

Stromboli in Italy (Finizola et al., 2002), and on Misti volcano in Peru (Finizola et al., 2004). In the present case, this method was useful to highlight the structural limits, which are usually preferential paths for ground water circulation and to map the hydrothermal activity.

\subsection{Soil $\mathrm{CO}_{2}$ flux}

Soil $\mathrm{CO}_{2}$ flux measurements were acquired using the methodology described by Chiodini et al. (1998). The instrumentation consists of an IR spectrometer Licor LI800 with a range of 0 to $2000 \mu \mathrm{mol} / \mathrm{mol}(2 \mathrm{vol} . \%)$, an accumulation chamber (type A: volume of $30 \mathrm{~cm}^{3}$ ) and a palmtop to plot the $\mathrm{CO}_{2}$ increase as a function of time. The accumulation chamber is leaned on the ground so that the atmospheric air cannot penetrate inside. The gas permeating from the soil accumulates in the dead volume, passes through the IR spectrometer and is re-injected in the accumulation chamber. The increase of the concentration in the chamber through time allows determining the flux of $\mathrm{CO}_{2}$ from the soil. This is a powerful method to detect preferential hydrothermal flux paths on a volcanic edifice.

\subsection{Temperature at $30 \mathrm{~cm}$ depth}

Temperature measurements were performed at a depth of $30 \mathrm{~cm} \pm$ $1 \mathrm{~cm}$ and respecting a stabilisation time of $15 \mathrm{~min}$. We used thermal probes and a digital thermometer with a sensitivity of $0.1^{\circ} \mathrm{C}$. The maximum amplitude of diurnal variation at Vulcano at $30 \mathrm{~cm}$ depth during the summer season is less than $1.2^{\circ} \mathrm{C}$ (Chébli, 1997; Aubert et al., 2007). During the year, at that depth, the temperature varies from 12.2 to $27.2^{\circ} \mathrm{C}$ in January and August, respectively (Lo Cascio and Navarra, 1997). Consequently, for measurements performed at $30 \mathrm{~cm}$ depth, we consider a temperature above $30^{\circ} \mathrm{C}$ as a signature of hydrothermal fluid circulations.
We made a temperature map interpolated from the data of the nine profiles (Fig. 3a). The data have been acquired within one year so that the amplitude of the thermal anomalies probably varied along the period of acquisition of the dataset due to seasonal and internal variations. However this figure gives reliable qualitative information.

\section{Results}

\subsection{Reliability of the temperature, $\mathrm{CO}_{2}$ and $\mathrm{SP}$ maps}

A map is supposed to present the state of a particular area within a short period of time, which suggests that the conditions along the acquisition of a dataset must remain relatively stable. Our dataset contains data from three surveys performed in a one year period (from October 2005 to October 2006). Concerning the SP measurements, we added a few data from a survey of 2004 (black dots on Fig. $3 \mathrm{~b}$ ) in order to join the profiles to the sea, calculate a closure offset and distribute linearly this offset on the profiles to correct the global dataset presented here. Knowing that, we must take into account that some parameters influencing the measurements have undergone some variations, which can distort the maps. These parameters are the volcanic activity, the soil characteristics and the atmospheric conditions.

It seems that the temperature measurements at $30 \mathrm{~cm}$ depth are less affected by the variations undergone between our three surveys. It is true since the measurements are not performed during rain events. In fact the rain makes the temperature fall down of several degrees depending on the depth of infiltration of the meteoric water and the atmospheric temperature.

For the SP map, some strong positive and negative anomalies remain uncorrelated with the other methods and the main

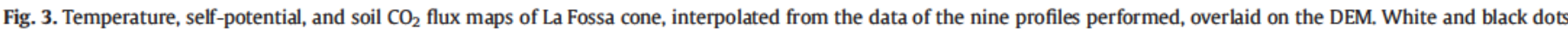
represent the measure points. PN (Punte Nere), Pa (Palizzi), FV (Forgia Vecchia), PC (Pietre Cotte), and GC (Gran Cratere) craters are localised with white dashed lines. 

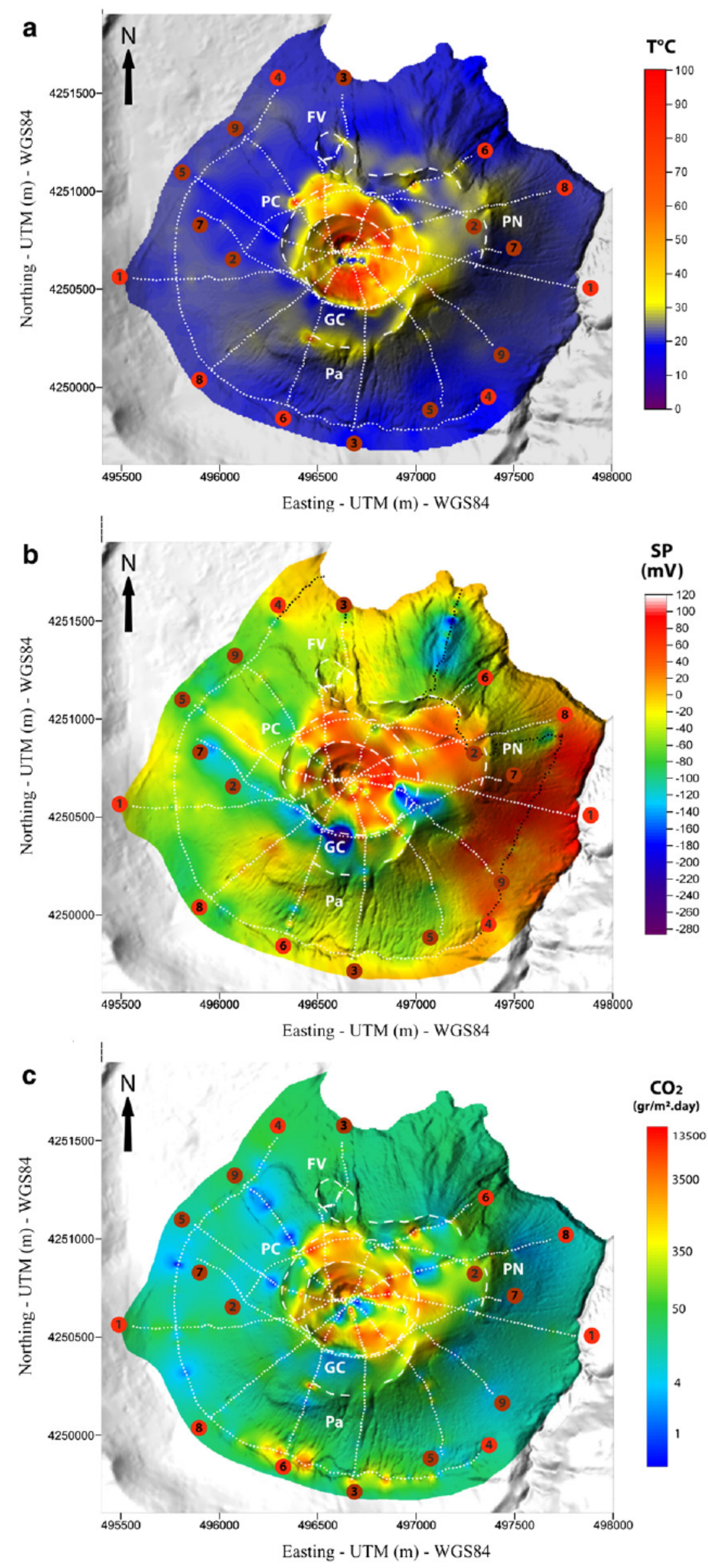
information is displayed in the PC/GC crater area and the PN crater. Variations of the volcanic activity, seasonal variations of the soil moisture are the possible responsible of some of the unexplained anomalies. The contrasts of resistivity of the terrain can also affect the SP measurements without affecting the $\mathrm{CO}_{2}$ and temperature values.

The values of the soil diffuse degassing at La Fossa volcano during the last crisis, begun at the end of 2004, revealed fluctuations of $\mathrm{CO}_{2}$ flux until one order of magnitude (Granieri et al., 2006). It was characterized by significant variations in the extension of the anomalous degassing area. The $\mathrm{CO}_{2}$ flux data presented in this paper were collected in three different periods during the last crisis of La Fossa volcano. Consequently, the resulting $\mathrm{CO}_{2}$ map of the entire La Fossa cone shown in Fig. $3 \mathrm{c}$ is purely indicative because of the fluctuations in the degassing activity and no quantitative analyses can be done. Nevertheless the $\mathrm{CO}_{2}$ map closely reflects the shape of the anomalous degassing areas presented by Granieri et al. (2006).

Finally, more than giving quantitative information, the temperature, $\mathrm{SP}$, and $\mathrm{CO}_{2}$ maps are useful to get qualitative information, i.e. structural information and a distribution of the hydrothermal emissions. Based on the correlations between these maps, several areas of interest have been identified and will be commented below.

\subsection{The central hydrothermal system}

In an interpolated map, the less the profiles are spaced, the more the interpolation is reliable so that, on the temperature, $\mathrm{SP}$, and $\mathrm{CO}_{2}$ maps, the most relevant information is concentrated around the data points (white and black dots on Fig. 3). The most striking information provided by the global temperature map (Fig. 3a) is that the main thermal anomaly is bounded by the rim of the GC and PC craters, which are the most recent craters formed on La Fossa cone. This central thermal anomaly is correlated to anomalies of similar extension in SP and soil $\mathrm{CO}_{2}$ flux (maps in Fig. 3b and c).

The highest temperatures have been measured into the inner crater. Gases escape from the fumaroles at high temperature $\left(\sim 400^{\circ} \mathrm{C}\right)$ and, for the safety of the measuring devices, no measurement was made right on it. In the north-east area, the thermal, SP and $\mathrm{CO}_{2}$ anomalies extend beyond the $\mathrm{GC}$ rim, between the $\mathrm{GC}$ and the PC crater rims. In the field, these zones correspond to strong fumarolic activity and/or extensive hydrothermal alteration. The main fumarolic field is indeed located on the northern wall of the GC crater, on the rim, and extends beyond its limits (see Bukumirovic et al., 1997). On Vulcano, the temperatures of the fumaroles can reach several hundred degrees Celsius (almost $700{ }^{\circ} \mathrm{C}$ during the 1977 crisis, see Barberi et al. (1991)). Except on these particular locations, no measurement of our surveys overtakes $98^{\circ} \mathrm{C}$. This can be explained by the presence, at depth, of a hot aquifer or of a shallow condensation zone formed under a sealed layer, acting as a thermal buffer between the magmatic heat source and the surface (Montalto 1994; Aubert et al., 2007).

These main thermal, $\mathrm{SP}$, and $\mathrm{CO}_{2}$ anomalies are the expression of the central active hydrothermal system activity and the data show that this hydrothermal system is bounded by the PC and GC crater faults.

\subsection{Hydrothermal circulations along former structural limits}

Hydrothermal fluid circulation is not restricted to the central crater area. Outside of the main Fossa craters area, we also identified few temperature, SP, and $\mathrm{CO}_{2}$ anomalies. Not far from the central hydrothermal system, strong anomalies have been observed beyond the PC crater rim, on the north-west upper flank of the cone, right on the former footpath to the summit (see the central part of Profile 2 in Fig. 3). These high temperatures, $\mathrm{SP}$, and $\mathrm{CO}_{2}$ values are associated with fumarolic emissions.

\subsubsection{Forgia Vecchia crater}

On the northern flank, the Forgia Vecchia crater (FV) is affected by a thermal anomaly on its northern border (see northern section of Profile 3 on Fig. 3a). The temperature measured is $\sim 10{ }^{\circ} \mathrm{C}$ above the mean temperature in this area. This is the only sign of current activity on this adventive crater, in our dataset. The FV crater border is a permeable limit acting as a guide for fluid circulation. The thermal release noticed here can be due to the presence, at shallow depth, of a still cooling magmatic batch related to the past activity. Another source could be distal hot-fluid circulations associated to the current hydrothermal system of La Fossa cone.

\subsubsection{Palizzi crater}

On the southern flank of the edifice, Profiles 3, 5, and 6 display thermal and $\mathrm{CO}_{2}$ anomalies on their intersection with the Pa crater rim. This crater rim is clearly underlined, even when the topography gives no evidence for it. The location of the anomalies coincides with the crater drawn by De Astis et al. (2007) in their geological map of Vulcano.

\subsubsection{Punte Nere crater}

One striking result is the observation of high temperature, SP, and $\mathrm{CO}_{2}$ values in the area enclosed by the Punte Nere crater (PN), where no eruptive activity took place since $3.8 \mathrm{ka}$ (De Astis et al., 2007). As shown by the data along the two profiles crossing the rim in the North (Profile 6) and in the East (Profile 8), the thermal and $\mathrm{CO}_{2}$ anomalies extend outside the PN crater, on the upper part of the slope of the cone.

Two types of thermal anomalies can be distinguished in this area, which are (1) strong anomalies (in the range between $35^{\circ} \mathrm{C}$ and $60^{\circ} \mathrm{C}$ ) along structural limits and (2) weak anomalies (smaller than $35^{\circ} \mathrm{C}$ ) in areas poorly or unaffected by faulting. On Profiles 6 and 8 , the temperature anomalies show that hydrothermal fluids take advantage of the high permeability along the crater rim to reach the ground surface. The maximum temperature registered is $\sim 60^{\circ} \mathrm{C}$. In this case, the heat can come from a deep source and produce strong anomalies in the vicinity of the ground surface. Concerning the wide anomalous temperature field inside the PN crater, temperatures reach a maximum of $35^{\circ} \mathrm{C}$.

As for the FV crater but to a wider scale, the PN crater anomaly can have two potential origins: the hot-fluid source can be due either to circulations of fluids from La Fossa hydrothermal system or to remnants of the past activity of the Punte Nere cone. Profile 1 can help in determining the source (Fig. 4). As on the maps (Fig. 3), an overview of this profile shows high values of temperature, selfpotential, and $\mathrm{CO}_{2}$ in the central part of the edifice. The self-potential data display a typical $\mathrm{W}$ shape (e.g., Ishido, 2004), confirming that the main hydrothermal activity is concentrated in the limits of the GC crater. Crossing the eastern side of the GC crater rim, the temperature and $\mathrm{CO}_{2}$ progressively decrease from west to east, inside the PN crater. The anomaly vanishes to reach characteristic temperatures of "cold" zones on the flank of the edifice. At depth, the resistivity structure shows a continuous conductive zone from the most internal crater to the flank of the cone. In the limits of the PC crater, the low resistivity is associated to the hydrothermal system, i.e. hydrothermal fluids convecting through the detritic volcanic deposits of the last phases of eruptive activity. Beyond the PC crater, we interpret the low-resistivity layer as tuff deposits from La Fossa activity. The resistive body visible at depth acts as an impermeable limit so that the fluids are guided inside the more permeable overlying tuff level. Underground, the hot fluids rising from the central zone overflow to the east into the PN crater and progressively loose gases and heat. The temperature, $\mathrm{SP}$, and $\mathrm{CO}_{2}$ anomalies visible inside the PN crater can be attributed to this phenomenon, even if a contribution of a residual degassing activity of the PN volcanic centre cannot be ruled out. 


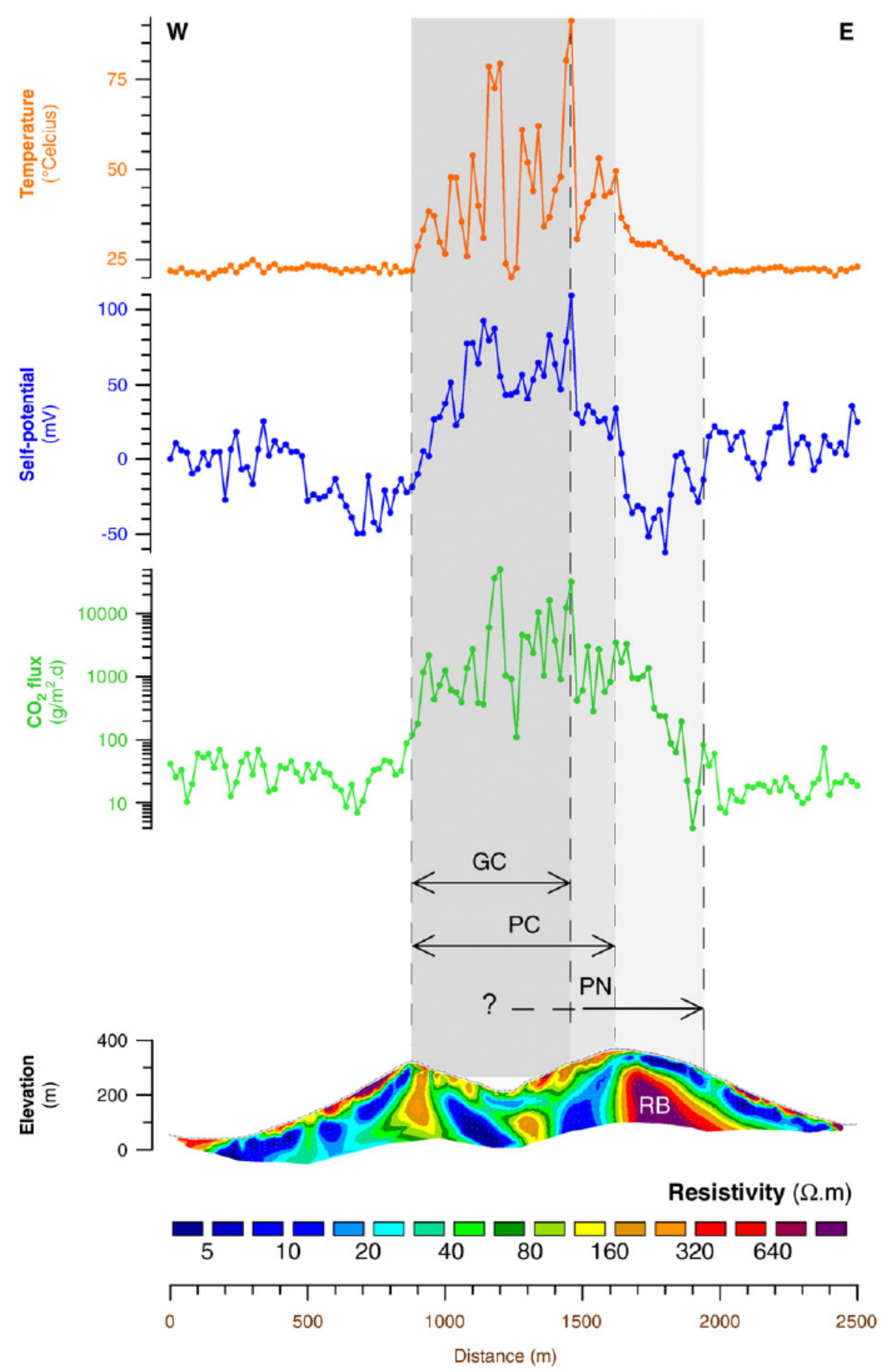

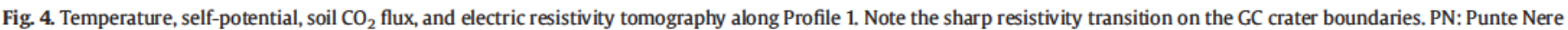
crater, PC: Pietre Cotte crater, GC: Gran Cratere crater.

\subsection{Regional faulting evidences in the Palizzi area}

Profile 4 was performed at the base of the cone, from Porto di Levante to an area situated to the East of Palizzi, near the Rio Grande bed. The $\mathrm{CO}_{2}$ map (Fig. 3c) shows remarkable anomalies in the Palizzi area. The global temperature map (Fig. 3a) does not display a perceptible anomaly along Profile 4 . However, a closer inspection of the data indicates a variation of $\sim 6^{\circ} \mathrm{C}$ from one extremity of the profile to the other (see Figs. 5 and 6). At the south-eastern end of the profile, the temperature is $\sim 18^{\circ} \mathrm{C}$. Following the profile to Porto di Levante, the temperature increases progressively and reaches a maximum of $\sim 24^{\circ} \mathrm{C}$. The data were acquired in only two days and with similar dry meteorological conditions all along this period of time. Moreover, this progressive temperature increase of $\sim 6{ }^{\circ} \mathrm{C}$ from the southern flank to the north-western flank of La Fossa cone exceeds the maximum amplitude of diurnal variation which is less than $1.2^{\circ} \mathrm{C}$ at Vulcano, for measurements performed at $30 \mathrm{~cm}$ depth during summer season (Chébli, 1997; Aubert et al., 2007). This makes $6^{\circ} \mathrm{C}$ a significant variation.

In the northern and southern parts of the profile, the ERT model shows a shallow resistive layer associated to pyroclastic deposits. These deposits are from the Gran Cratere phase of activity in the 

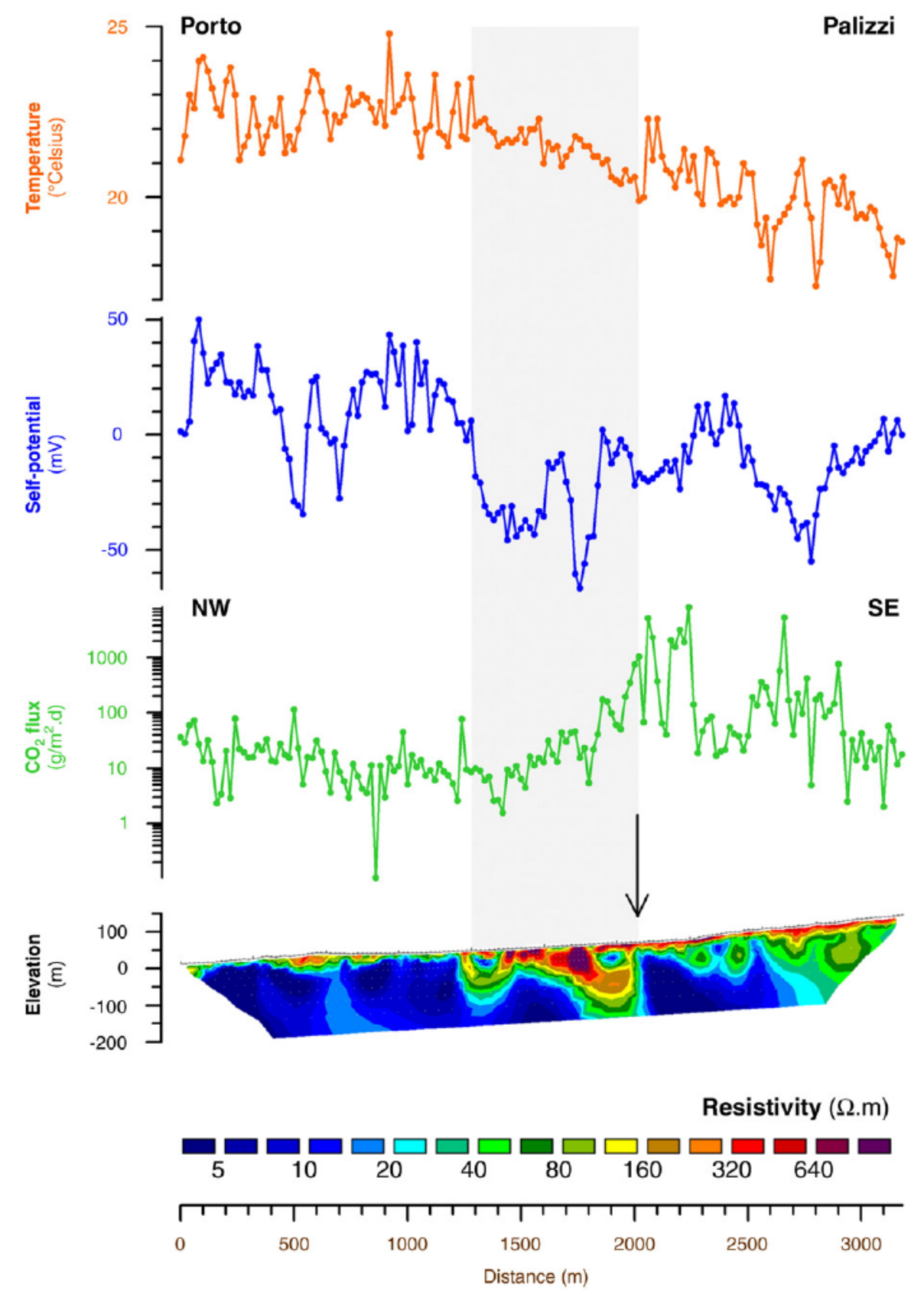

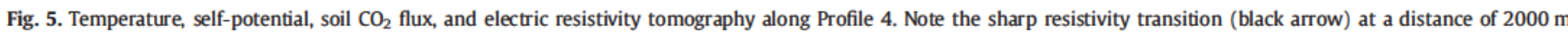
underlined by a temperature and soil $\mathrm{CO}_{2}$ flux maximum. The black arrow is also localized on map in Fig. 6.

northern portion of the profile and from the Palizzi phase in the south. This resistive layer of a few meters-thick overlays a low-resistivity medium $(<20 \Omega \mathrm{m})$. At the centre of the profile, we notice the presence of a high-resistivity zone. The thickness of this body globally increases from north to south. This structure is bounded by two vertical limits evidenced by sharp transitions of the resistivity. The northern boundary is rapidly blurring at depth. The southern boundary is marked by a sharpest transition of resistivity and runs from the shallow levels of the section, until the maximum depth of investigation.

On the northern part of the profile, the soil $\mathrm{CO}_{2}$ flux decreases from north to south consistently with the global decrease of temperature observed along the whole profile. In the vicinity of the resistive body, the $\mathrm{CO}_{2}$ flux increases, reaching a maximum in the area surrounding the southern vertical limit identified from the resistivity data. On the area surrounding the resistive body the short wave-length variations of the temperature are significantly lower than on the rest of the profile. Thereby, along our profile, the southern vertical limit of the resistive body marks a sharp increase of $\sim 2.5^{\circ} \mathrm{C}$ of the mean temperature from north to south. Right on the northern boundary of the body, we also observe a slight soil $\mathrm{CO}_{2}$ flux anomaly $\left(\sim 80 \mathrm{~g} / \mathrm{m}^{2} \mathrm{~d}\right)$ and a decrease of the SP signal $(\sim 50 \mathrm{mV})$.

Capasso et al. (2000) analysed partial pressures of $\mathrm{He}$ and $\mathrm{CO}_{2}$ of some water samples from the north-eastern quarter of La Fossa cone area. They observed that the values of these partial pressures were appreciably higher than those in waters in equilibrium with the atmosphere, therefore showing interaction between volcanic gases and groundwater. Our data are consistent with those results 


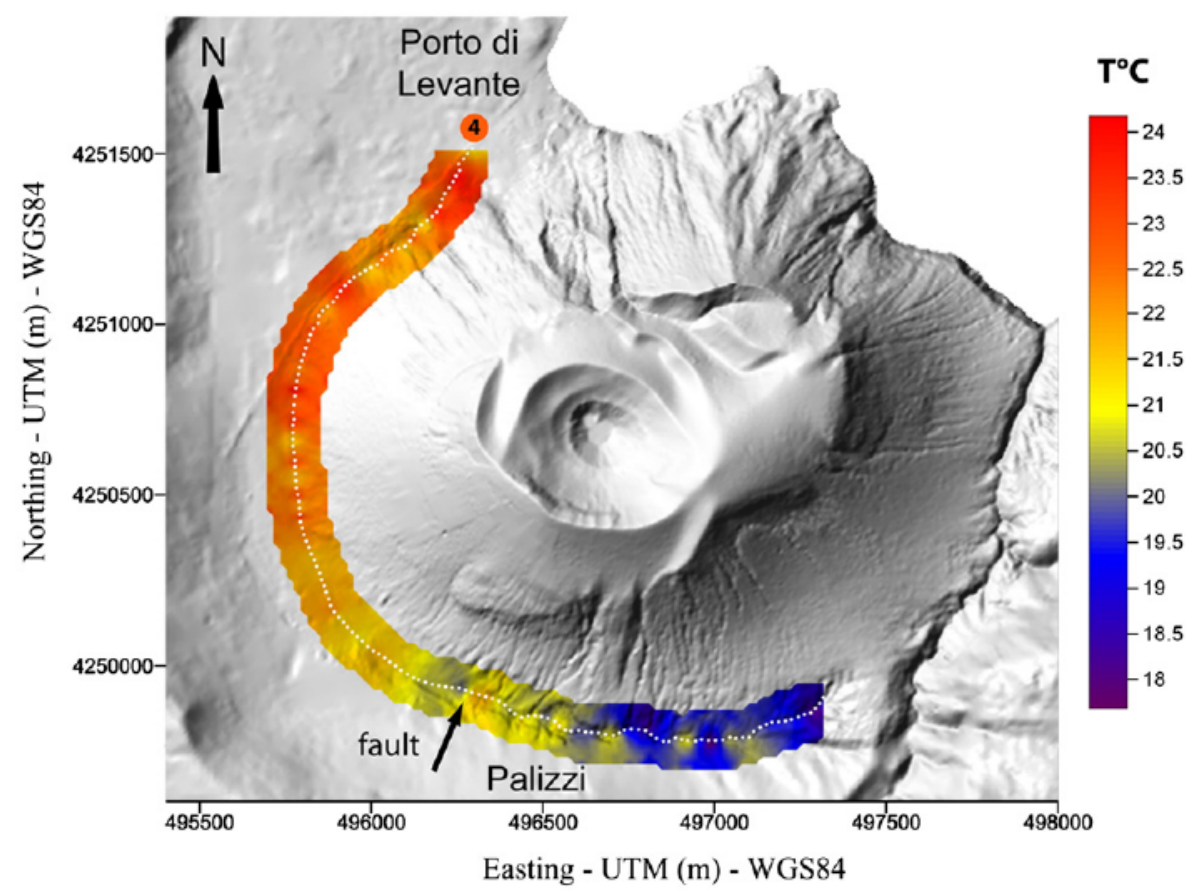

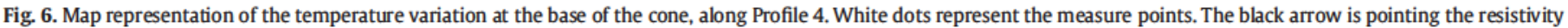
transition highlighted by electrical resistivity tomography (see Fig. 5).

and we interpret the gradient observed along Profile 4 as the evidence of preferential hot-fluid circulations at the base of the north-western flank of La Fossa cone. The peaks of $\mathrm{CO}_{2}$ flux in our data, around Palizzi are consistent with soil gas samples analysed by Capasso et al. (1997) in the same zone. The authors measured widespread exhalative manifestations dominated by $\mathrm{CO}_{2}$ on Palizzi that they interpreted in terms of hydrothermal circulation. The local anomalies we observed and the associated vertical limit pointed out by the ERT data lead us to interpret this signal as hydrothermal fluid circulation rising along a volcano-tectonic structure. This structure could be related to the NNW Tindari-Letojanni regional fault system, identified in the southern sector of La Fossa caldera (Barberi et al., 1994). The northern boundary of the resistive body is not deeply rooted as is the southern one. This limit is likely only a lithological transition. The resistive rocks, probably a lava flow pile or a lava dome, constitute an impermeable limit to fluid circulation. The anomalies registered here are likely due to circulation of fluids guided along the lithological boundary.

\subsection{Comparison between the data and the geology}

\subsubsection{Signals associated to the various volcanic formations}

The ERT data allow visualizing almost the entire cone above sea level. The profiles detailed in the following paragraphs cross the main structures identified on the volcanic edifice. In the first layers of the sections, the ERT data can be easily correlated to field observations. Indeed, in all the profiles, the Gran Cratere grey ash formation appears as a high-resistivity layer (see Figs. 4, 5, 7, 8). At the base of this resistive layer, the sharp transition in electrical resistivity can be interpreted as a sharp lithological transition. Thereby this interface can be followed at depth, along the slopes of the cone. The ERT sections display a thickness of $\sim 20-30$ m which could be attributed to the presence of the Gran Cratere, the Pietre Cotte and, the Forgia Vecchia formations.

The tuff outcrops, mostly corresponding to the Palizzi and Caruggi pyroclastic formations, are correlated to low-resistivity values $(<20 \Omega$ $\mathrm{m})$. This is visible in various outcrops as in the northern part of Profile
6 (Fig. 7). These low-resistivity values result from the cation exchange capacity of clay minerals and zeolites composing the Vulcano tuff and are indicative of the alteration of the rock (see Roberts and Lin, 1997; Revil et al., 2002; Bernard et al., 2007).

Also in the southern part of Profile 8, the GC crater cliff shows the succession of an upper electrical resistive layer overlying a conductive layer (Fig. 8). In the field they are related respectively to (1) the Gran Cratere ash and Pietre Cotte deposits and (2) to the Caruggi tuff deposits (see the simplified geologic map of Fig. 1).

\subsubsection{Signals associated to the fumaroles}

In the field, the fumaroles are concentrated along the most recent crater rims. The fumarolic fields inside the GC crater coincide with very low-resistivity values, in the same order of magnitude than the tuffs deposits. The difference between "cold" tuffs and rocks affected by hydrothermal convection is highlighted by field observations, selfpotential, temperature, and $\mathrm{CO}_{2}$ flux measurements. Profile 6 shows highly conductive terrains $(<20 \Omega \mathrm{m})$ right under the most active fumaroles of La Fossa cone (Fig. 7). These conductive values are correlated with a temperature anomaly reaching $95^{\circ} \mathrm{C}$, a positive selfpotential anomaly of $100 \mathrm{mV}$ (variation with respect to the mean SP value in this zone) and a $\mathrm{CO}_{2}$ flux peak reaching $~ 10,000 \mathrm{~g} / \mathrm{m}^{2} \mathrm{~d}$ in the vicinity of the fumaroles. The most striking feature is the resistivity model showing a conductive channel running from the fumaroles at the surface, to the central hydrothermal system, until the maximum depth of investigation. The channel is progressively widening with depth. It developed thanks to a pre-existent structural limit, which is the GC crater.

\subsubsection{Signals associated to crater boundaries}

The craters identified through the morphology of the edifice and from a previous work (De Astis et al., 2007) are correlated with sharp horizontal transitions of resistivity forming more or less vertical limits. The best example is given by the south-west border of the GC crater which is crossed by Profiles 1 and 8 (Figs. 4 and 8). It displays a vertical to slightly reverse-slope border delimiting high resistivities $(>150 \Omega$ $\mathrm{m})$ outside the crater and low resistivities $(<20 \Omega \mathrm{m})$ inside the crater. 


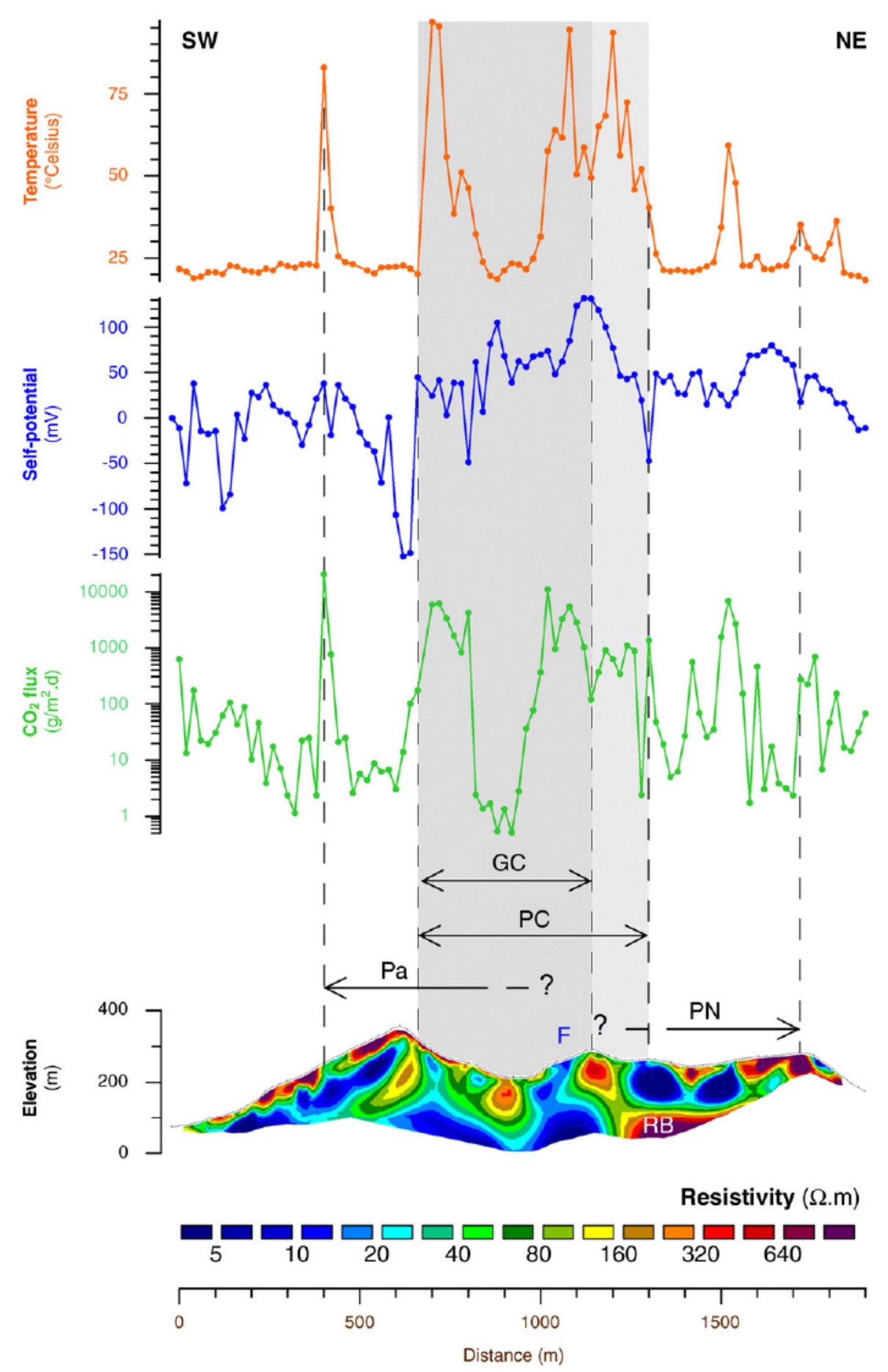

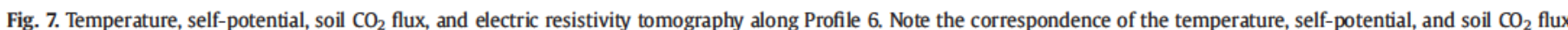
anomalies with low values of resistivities reaching the surface. PN: Punte Nere crater, PC: Pietre Cotte crater, GC: Gran Cratere crater, F: fumaroles.

As seen before, at the surface, a clear anomaly in temperature, selfpotential, and $\mathrm{CO}_{2}$ flux, spots this boundary, at the base of the crater cliff. This type of configuration, related to a structural limit, can be observed for most of the crater rims identified.

The reverse dip of the crater border faults is a common consequence of caldera-type or pit-crater-type collapse of a crater roof (e.g. Anderson, 1936; Branney, 1995; Acocella et al., 2000; Roche et al., 2000, 2001; Walter and Troll, 2001). Therefore, GC crater could have been affected by this type of collapse during its formation. A similar dipping is not observed on the north-eastern border maybe because the collapse was asymmetric. Hydrothermal circulations and alteration in the vicinity of the eastern magma body evidenced under the PN crater could also have modified the resistivity distribution appearing nowadays and distort the observation on this side (Cf. next Section 4.6. The Eastern electrical resistive body).

\subsection{The eastern electrical resistive body}

On all the sections crossing the eastern half of the edifice, a wide resistive body has been highlighted inside the PN crater, buried under 


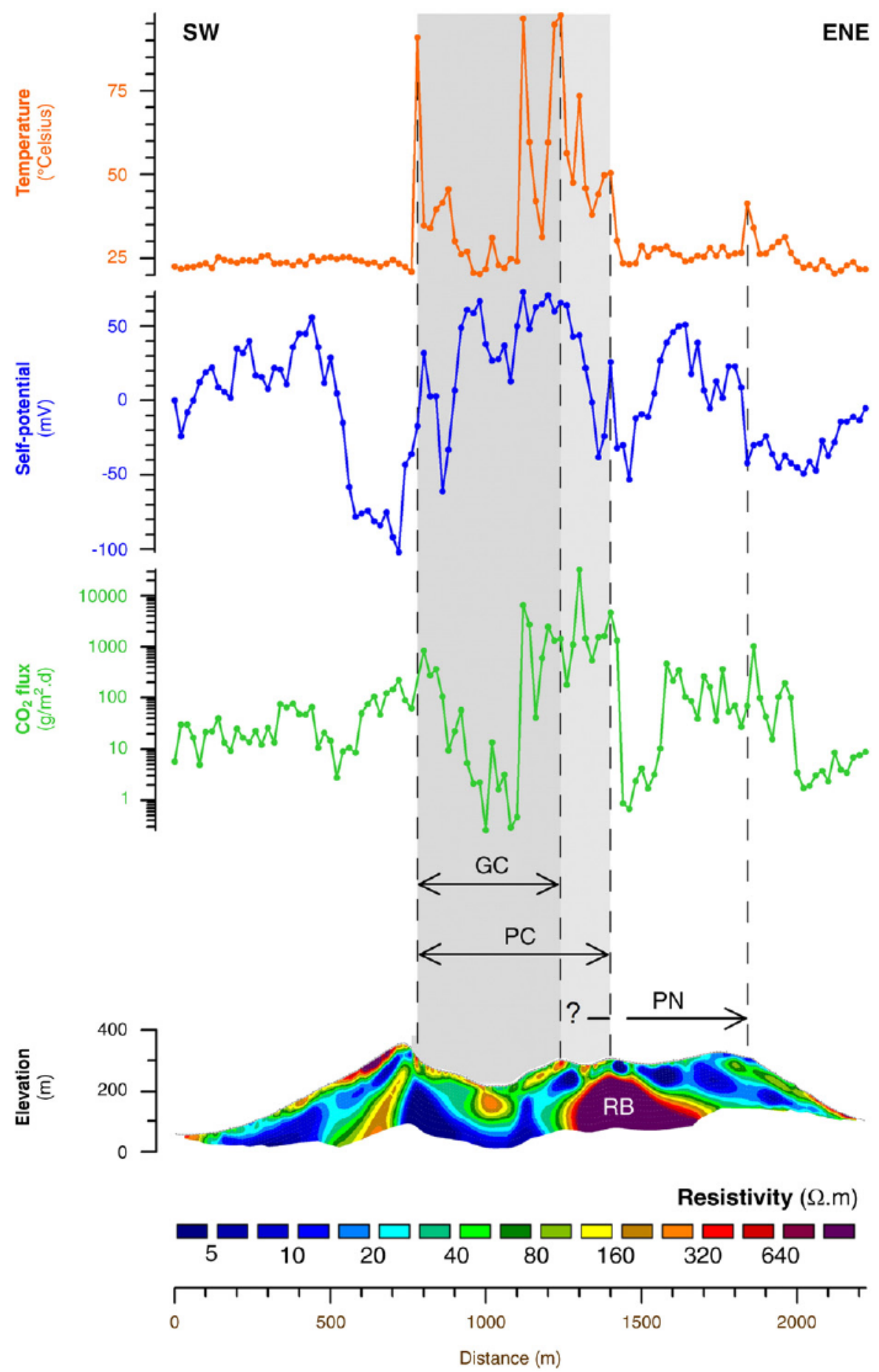

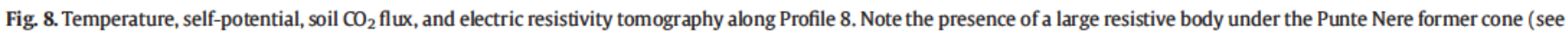
also Profile 1 on Fig. 4). PN: Punte Nere crater, PC: Pietre Cotte crater, GC: Gran Cratere crater.

younger formations. Profiles 1, 5, 6, 7, 8, and 9 (see Fig. 2 for position of the profiles) clearly show a zone of resistivities ranging from $200 \Omega \mathrm{m}$ to $1000 \Omega \mathrm{m}$, at depth. These high-resistivity zones are in the range of the values expected for a lava flow pile or intrusive rocks (a dyke system, a shallow magma batch or a dome; e.g., see Figure 1.5 of Loke, 2004). The resistivity of the terrain depends mainly on the interconnected porosity of the rock and on the resistivity of the pore fluids. As an example, in a dome, a significant proportion of the vesicles are isolated and refilled by volcanic gas (e.g., see Ramsey and Fink, 1999) which confers a high resistivity to the rock.
It is important to notice that the inversion of ERT data tends to smooth the resistivity transitions i.e. the interfaces between the different geologic units. The boundary of the electrical resistive body is delimited by a sharp variation of the resistivity values, which can be associated to a lithological transition. On the resistivity models, the sharper transition is observed for an average value of $\sim 160 \Omega \mathrm{m}$. Based on this assessment, the minimum depth of the resistive body can be estimated to $\sim 50 \mathrm{~m}$. This suggests that this unit is buried under additional formations than just the Gran Cratere pyroclastic deposits. 


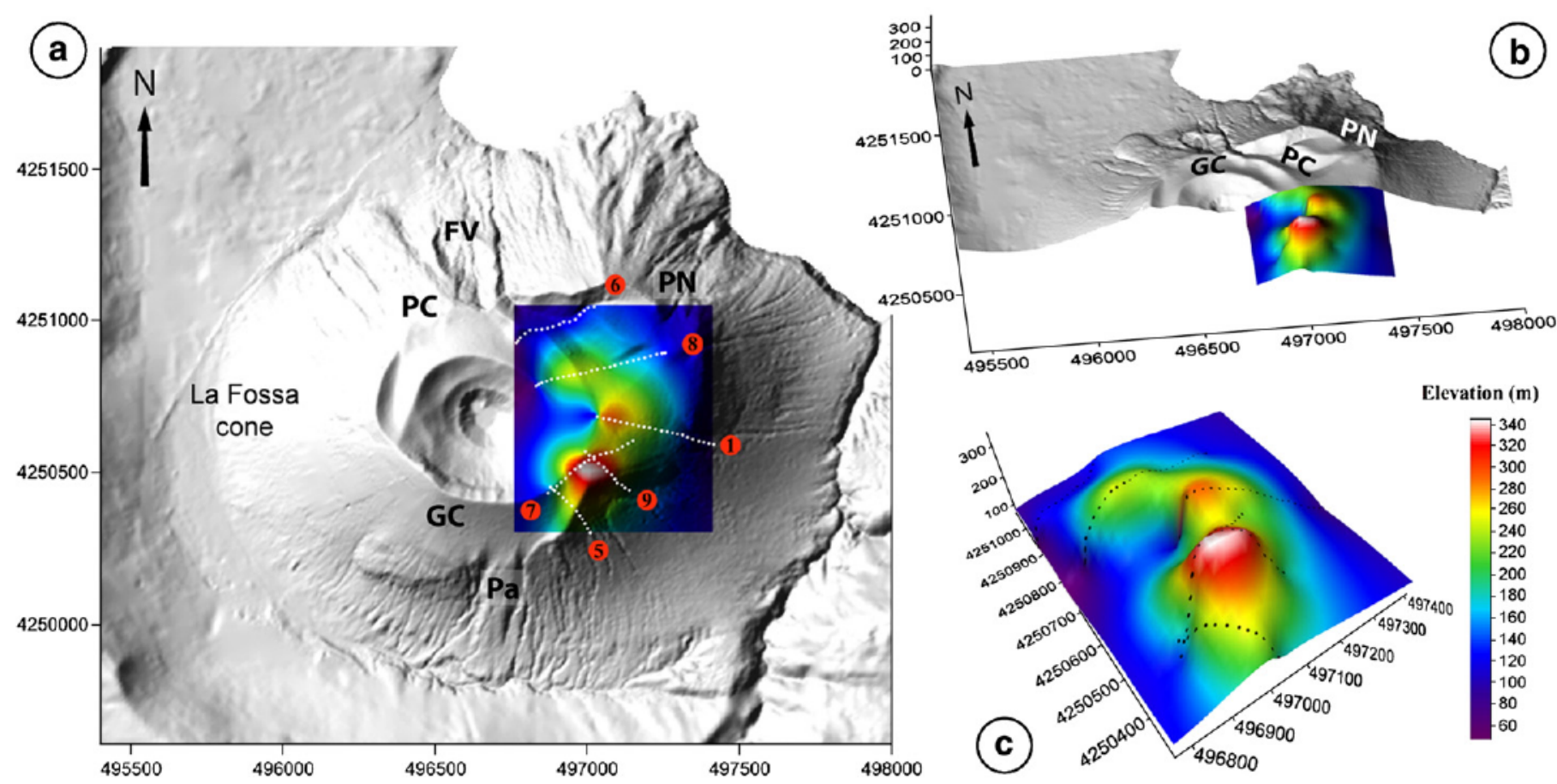

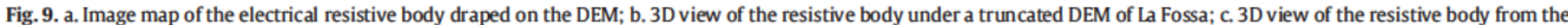

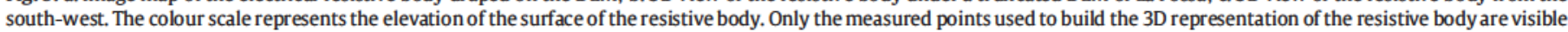
(black and white dots). PN: Punte Nere, Pa: Palizzi, FV: Forgia Vecchia, PC: Pietre Cotte, and GC: Gran Cratere. Coordinates are in meter, UTM (WGS84).

The density of the inverted resistivity data allowed us to reconstruct the shape of this resistive body buried inside the Punte Nere crater. To this purpose, the six ERT profiles cited above have been used. On each profile, the $160 \Omega \mathrm{m}$ isoresistivity line has been digitized with one point every $20 \mathrm{~m}$ (in the horizontal plane). The $\mathrm{XYZ}$ coordinates obtained were interpolated and represented as a surface map (Fig. 9).

The lateral and vertical maximum extension of the body is not accessible as it extends under the depth of investigation. It displays a crescent shape with an irregular surface. The eastern side is a more or less regular slope, slightly steeper than the topographic surface while, to the West, the resistive body ends with a vertical boundary. This straight western limit coincides nicely with the PC crater rim.

Blanco-Montenegro et al. (2007) found a magnetic anomaly inside the PN crater. The authors interpreted this anomaly as a pile of tephritic lavas emplaced in an early phase of activity of La Fossa cone. From our ERT data, the shape, position and range of resistivity of this body led us to interpret it as an intrusion or a dome contemporary of the activity of the PN cone (5.3 ka-3.8 ka) and truncated to the west, on at least $200 \mathrm{~m}$ depth by the PC crater ring fault during its formation (1739 A.D.) (see Fig. 10). The presence of this large buried magma body, if it is not totally cooled down and degassed, can contribute to the thermal and $\mathrm{CO}_{2}$ flux anomalies observed inside the PN crater (Fig. 8).

\section{Conclusions}

All the geophysical and geochemical anomalies we evidenced at the surface of La Fossa cone are controlled by structural limits. The main hydrothermal system is enclosed by the boundaries of the PC and GC craters. This is indicated by the low-resistivity value of the formations and by the strong self-potential, $\mathrm{CO}_{2}$ flux, and temperature anomalies measured in the limits of these craters. The hydrothermal activity is not restricted to the central part of the edifice. In the periphery, hydrothermal circulations have been evidenced and are, most of the time, clearly influenced by the structure of the edifice. This structure corresponds either to lithological levels or to structural limits and the following conclusions have been reached:

(1) The hydrothermal fluids rising from the central hydrothermal system of the GC crater condensate at shallow depth and partly flow down to the PN crater, through the more permeable levels. They are guided along the PC crater border and the resistive body highlighted at depth by electrical resistivity tomography.

(2) The Palizzi area is affected by circulations of hydrothermal fluids associated to the presence of a vertical structural limit visible in the resistivity tomography at the base of the edifice. This fault reaching more than $100 \mathrm{~m}$ b.s.l. could be attributed to the NNW regional volcano-tectonic orientation affecting the island of Vulcano.

(3) The former-crater rims, even when partially buried, remain preferential paths for hydrothermal fluid circulations as evidenced for the FV, PN, and Pa craters, which are underlined by strong temperature and $\mathrm{CO}_{2}$ degassing anomalies and associated with low-resistivity values at depth.

Circulations of hydrothermal fluids have been evidenced at the base of the north-western flank, by a variation of temperature of $\sim 6{ }^{\circ} \mathrm{C}$ from the south-east to the north-west along the Profile 4. Such a distal anomaly of temperature can be due either to rising hydrothermal fluids or to fluids contaminated by the hydrothermal release in the summit area and flowing down to the base into shallow ground levels of the north-western flank. The north-western end of Profile 4 could be a relevant site for monitoring the temperature variations, if the fluctuations of the main hydrothermal system activity influence also the hydrothermal circulations at the base of the cone.

Our study also reveals the presence of an old magmatic body, dome or shallow intrusion, associated to the activity of the Punte Nere cone. The PC crater intersects this magma body on $200 \mathrm{~m}$ high, destructing its western part during the formation of the crater. The interface between the resistive body and the deposits filling the inner crater is one of the major structural limits of the edifice and constitute the eastern limit of the main hydrothermal system of La Fossa cone. 

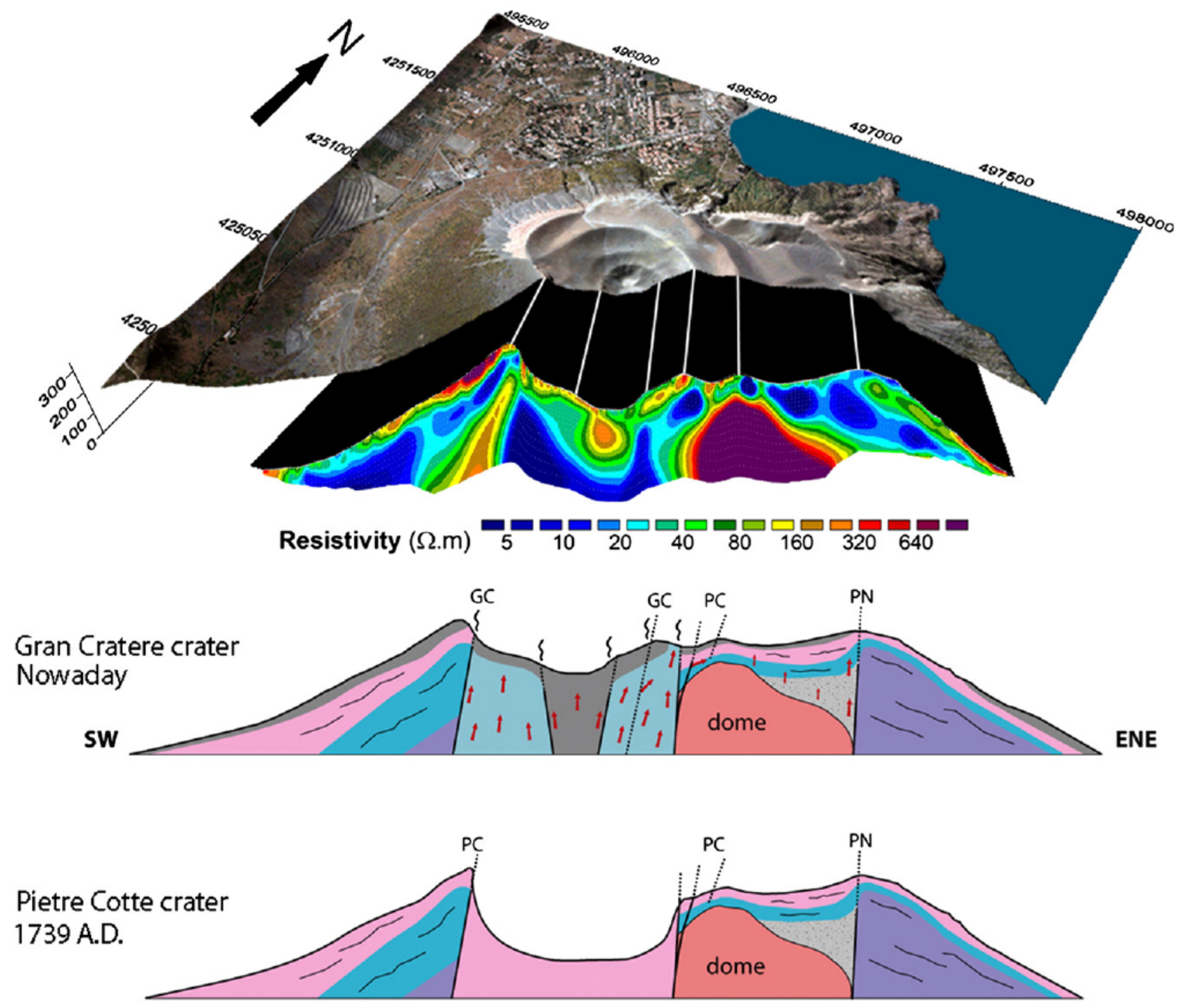

Punte Nere crater

$5.3-3.8 \mathrm{ka}$

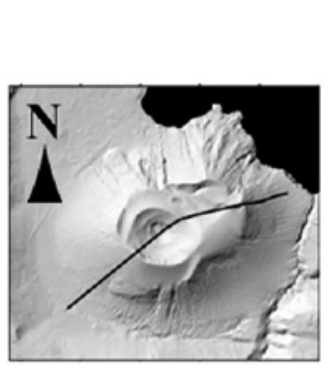

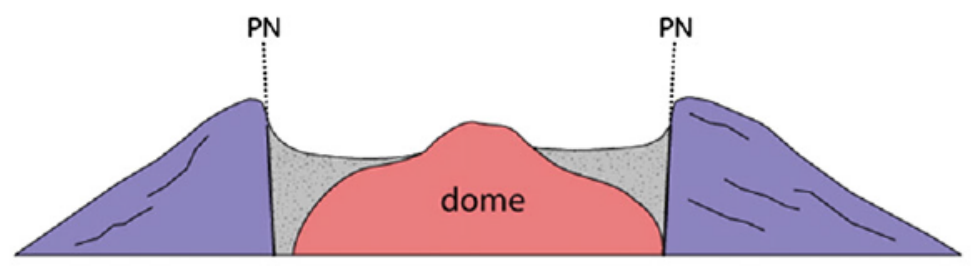

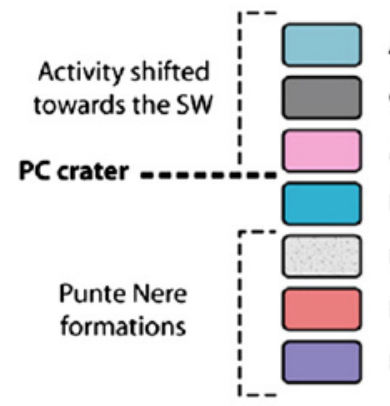

Main hydrothermal system

Gran Cratere grey ash

Mostly tuff deposits (Caruggi, Forgia Vecchia, Pietre Cotte)

Lava flows and pyroclastic deposits (Palizzi?)

Detritic deposits

Intrusive body

Punte Nere Formations
\ Fumaroles

f Hydrothermal fluid circulation

Fig. 10. Schematic representation of the evolution of the cone, from Punte Nere to nowadays. The information on both the geology and on the fluid circulation is shown. The synthetic sketch is based on Profile 8. PN: Punte Nere crater, PC: Pietre Cotte crater, GC: Gran Cratere crater. 


\section{Acknowledgments}

We thank Xavier Rassion for his help in the field. A special thanks to Maria Marsella for providing us the high resolution orthophoto and the digital elevation model of Vulcano Island. We also thank Gianfilippo De Astis for helpful discussions and for providing us a digital version of the geological map of Vulcano Island. The INSU-CNRS, Istituto di Metodologie per l'Analisi Ambientale (IMAA) del CNR, the Laboratoire GéoSciences Réunion-IPGP, the CNR, the Istituto Nazionale di Geofisica e Vulcanologia (INGV), and the Dipartimento per la Protezione Civile through the DPC Projects (Sub-project V3.5 Vulcano, Agreement 2005-2007) are thanked for financial supports. We also thank Andrea Borgia for interesting discussions. This is IPGP contribution number: 2446. We thank the editor, Joan Marti, an anonymous referee, and JeanFrançois Lénat for their very useful comments on our manuscript.

\section{References}

Acocella, V., Cifelli, F., Funiciello, R., 2000. Analogue models of calderas and resurgent domes. J. Volcanol. Geotherm. Res. 104, 81-96.

Allard, P., Carbonnelle, J., Dajlevic, D., Le Bronec, J., Morel, P., Robe, M.C., Morenas, J.M., Faivre-Pierret, R., Martin, D., Sabroux, J.C., Zettwoog, P., 1991. Eruptive and diffuse emissions of $\mathrm{CO}_{2}$ from Mount Etna. Nature 351, 387-391.

Anderson, E.M., 1936. The dynamics of the formation of cone sheets, ring dikes, and cauldron subsidences. Proc. R. Soc. Edinb. 56, 128-163.

Arrighi, S., Tanguy, J.-C., Rosi, M., 2006. Eruptions of the last 2200 years at Vulcano and Vulcanello (Aeolian Islands, Italy) dated by high accuracy archeomagnetism. Phys. Earth Planet. Inter. 159, 225-233. doi:10.1016/j.pepi.2006.07.010.

Aubert, M., Baubron, J.-C., 1988. Identification of a hidden thermal fissure in volcanic terrain, using a combination of hydrothermal convection indicators and soilatmosphere analysis. J. Volcanol. Geotherm. Res. 35, 217-225.

Aubert, M., Lima, E., 1986. Hydrothermal activity detected by self-potential measurements (SP) at the N-S volcanic axis between the volcanoes "Nevado de Colima" and "Fuego de Colima", Mexico. Geophys. J. Int. 25-4, 575-586.

Aubert, M., Diliberto, S., Finizola, A., Chébli, Y., 2007. Double origin of hydrothermal convective flux variations in the Fossa of Vulcano (Italy). Bull. Volcanol. doi:10.1007 s00445-007-0165-y.

Auken, E., Christiansen, A.V., 2004. Layered and laterally constrained 2D inversion of resistivity data. Geophysics $69,752-761$.

Barberi, F., Neri, G., Valenza, M., Villari, L., 1991. 1987-1990 unrest at Vulcano. Acta Vulcanol. 1, 95-106.

Barberi, F., Gandino, A., Gioncada, A., La Torre, P., Sbrana, A., Zenucchini, C., 1994. The deep structure of the Eolian Arc (Filicudi-Panarea-Vulcano sector) in light of gravimetric magnetic and volcanological data. J. Volcanol. Geotherm. Res. 61, 189-206.

Baubron, J.C., Allard, P., Toutain, J.P., 1990. Diffuse volcanic emissions of carbon dioxyde from Vulcano Island, Italy. Nature 344, 51-53.

Bernard, M.-L., Zamora, M., Géraud, Y., Boudon, G., 2007. Transport properties of pyroclastic rocks from Montagne Pelée volcano (Martinique, Lesser Antilles). J. Geophys. Res.112, B05205. doi: $10.1029 / 2006$ JB004385.

Binley, A., Kemna, A., 2005. DC Resistivity And Induced Polarization Methods. In: Rubin, Y, Hubbard, S. (Eds.), Hydrogeophysics. Springer, New York, pp. 129-156. chap. 5.

Blanco-Montenegro, I., de Ritis, R., Chiappini, M., 2007. Imaging and modelling the subsurface structure of volcanic calderas with high-resolution aeromagnetic data at Vulcano (Aeolian Islands, Italy). Bull. Volc. 69, 643-659. doi:10.1007/s00445-006-0100-7.

Branney, M.J., 1995. Downsag and extension at calderas: new perspectives on collapse geometries from ice-melt, mining, and volcanic subsidence. Bull. Volcanol. 57, 303-318.

Bukumirovic, T., Italiano, F., Nuccio, P.M., 1997. The evolution of a dynamic geological system: the support of a GIS for geochemical measurements at the fumarole field of Vulcano, Italy. J. Volcanol. Geotherm. Res. 79, 253-263.

Capasso, G., Favara, R., Inguaggiato, S., 1997. Chemical features and isotopic composition of gaseous manifestations on Vulcano Island, Aeolian Islands, Italy: an interpretative model of fluid circulation. Geochim. Cosmochim. Acta 61 (16), 3425-3440.

Capasso, G., Favara, R., Inguaggiato, S., 2000. Interaction between fumarolic gases and thermal groundwaters at Vulcano Island (Italy): evidences from chemical composition of dissolved gases in waters. J. Volcanol. Res. 102, 309-318.

Cecchi, E., Wyk, Van, de Vries, B., Lavest, J.-M., 2005. Flank spreading and collapse of weak-cored volcanoes. Bull. Volcanol. 67, 72-91.

Chébli, Y., 1997. Tomographie thermique et géoélectrique du cratère du Vulcano. Mémoire de D.E.A. Processus Magmatiques et Métamorphiques-Volcanologie. Université Blaise Pascal, Clermont-Ferrand II. 60pp.

Chiodini, G., Cioni, R., Guidi, M., Marini, L, Raco, B., 1998. Soil $\mathrm{CO}_{2}$ flux measurements in volcanic and geothermal areas. Appl. Geochem. 13, 543-552.

Day, S.J., 1996. Hydrothermal pore fluid pressure and the stability of porous, permeable volcano. Volcano Instability on the Earth and Other Planets: In: McGuire, W.J., Jones, A.P., Neuberg, J. (Eds.), Geol. Soc. Spec. Publ., vol. 110, pp. 77-93.

De Astis, G., Frazzetta, G., La Volpe, L, 1989. I depositi di riempimento della Caldera del Piano e i depositi della Lentia. Boll. G.N.V. (2), 763-778.

De Astis, G., La Volpe, L., Peccerillo, A., Civetta, L., 1997. Volcanological and petrological evolution of Vulcano island (Aeolian Arc, southern Tyrrhenian Sea. J. Geophys. Res. 102 (B4), 8021-8050.
De Astis, G., Ventura, G., Vilardo, G., 2003. Geodynamic significance of the Aeolian volcanism (Southern Tyrrhenian Sea, Italy) in light of structural, seismological, and geochemical data. Tectonics 22 (4), 14.1-14.17.

De Astis, G., Dellino, P., La Volpe, L., Lucchi, F., Tranne, C.A., 2007. Geological map of the Vulcano Island, 1:10000, L. La Volpe \& G. De Astis Eds.

De Rosa, R., Calanchi, N., Dellino, P.F., Francalanci, L., Lucchi, F., Rosi, M., Rossi, P.L, Tranne, C.A., 2004. 32nd International Geological Congress, Field Trip Guide Book - P42: Geology and volcanism of Stromboli, Lipari, and Vulcano (Aeolian Islands, vol. 5. Firenze 20-28 agosto 2004.

Dellino, P., La Volpe, L, 1997. Stratigrafia, dinamiche eruttive e deposizionali, scenario eruttivo e valutazioni di pericolosità a La Fossa di vulcano. In: La Volpe, L., Dellino, P., Nuccio, M., Privitera, E., Sbrana, A. (Eds.), CNR-GNV Progetto Vulcano 1993-1995. Felici, Pisa, pp. 214-237.

Durand, S., 1997. Etude structurale de la zone sommitale du Karthala (Grande Comore) par polarisation spontanée. Travail d'Etude et de Recherche. Univ. Blaise Pascal, Clermont-Ferrand II. 26 pp.

Finizola, A., Sortino, F., Lénat, J.-F., Valenza, M., 2002. Fluid circulation at Strombol volcano (Aeolian Islands, Italy) from self potential and $\mathrm{CO}_{2}$ surveys. J. Volcanol. Geotherm. Res. 116, 1-18.

Finizola, A., Sortino, F., Lénat, J.-F., Aubert, M., Ripepe, M., Valenza, M., 2003. The summit hydrothermal system of Stromboli: new insights from self-potential, temperature, $\mathrm{CO}_{2}$ and fumarolic fluids measurements, with structural and monitoring implications. Bull. Volcanol. 65, 486-504. doi:10.1007/s00445-003-0276-2.

Finizola, A., Lénat, J.-F., Macedo, O., Ramos, D., Thouret, J.-C., Sortino, F., 2004. Fluid circulation and structural discontinuities inside Misti volcano (Peru) inferred from self-potential measurements. J. Volcanol. Geotherm. Res. 135, 343-360.

Finizola, A., Revil, A., Rizzo, E, Piscitelli, S., Ricci, T., Morin, J. Angeletti, B., Mocochain, L. Sortino, F., 2006. Hydrogeological insights at Stromboli volcano (Italy) from geoelectrical, temperature, and $\mathrm{CO}_{2}$ soil degassing investigations. Geophys. Res. Lett. 33, L17304. doi:10.1029/2006GL026842.

Frazzetta, G., La Volpe, L., Sheridan, M.F., 1983. Evolution of the Fossa cone, Vulcano. J. Volcanol. Geotherm. Res. 17, 329-360.

Frazzetta, G., Gillot, P.Y., La Volpe, L., Sheridan, M.F., 1984. Volcanic hazards at Fossa of Vulcano: data from the last 6000 years. Bull. Volcanol. 47, 105-124.

Ghisetti, F., 1979. Relazioni tra strutture e fasi trascorrenti e distensive lungo i sistemi Messina-Fiumefreddo, Tindari-Letojanni e Alia-Malvagna (Sicilia nord-orientale): uno studio microtettonico. Geol. Rom. 18, 23-56.

Granieri, D., Carapezza, M.L., Chiodini, G., Avino, R., Caliro, S., Ranaldi, M., Ricci, T. Tarchini, L, 2006. Correlated increase in $\mathrm{CO}_{2}$ fumarolic content and diffuse emission from la Fossa crater (Vulcano, Italy): Evidence of volcanic unrest or increasing gas release from a stationary deep magma body? Geophys. Res. Lett. 33, L13316. doi: 10.1029/2006GL026460.

Griffiths, D.H., Barker, R.D., 1993. Two-dimensional resistivity imaging and modelling in areas of complex geology. J. Appl. Geophys. 29, 211-226.

Ishido, T., 2004. Electrokinetic mechanism for the "W"-shaped self-potential profile on volcanoes. Geophys. Res. Lett. 31, L15616. doi:10.1029/2004GL020409.

Keller, J., 1970. Die historischen eruptionen von Vulcano und Lipari. Zeit. Deut. Geol. Ges. $121,179-185$.

Keller, J., 1980. The island of Vulcano. Rend. Soc. Ital. Mineral. Petrol. 36, 369-414.

Lénat, J.F., Robineau, B., Durand, S., Bachèlery, P., 1998. Etude de la zone sommitale du volcan Karthala (Grande Comore) par polarisation spontanée. C. R. Acad. Sci. 327, 781-788.

Lo Cascio, P., Navarra, E., 1997. Guida Naturalistica Alle Isole Eolie. L'EPOS, Palermo. 112 pp.

Loke, M.H., 2004. Tutorial 2-D and 3-D electrical imaging surveys. Geotomo Software, Malaysia. $128 \mathrm{pp}$.

Loke, M.H., Barker, R.D., 1996. Rapid least-square inversion of apparent resistivity pseudosections by a quasi-Newton method. Geophys. Prospect. 44, 131-152.

López, D.L., Williams, S.N., 1993. Catastrophic volcanic collapse: relation to hydrothermal processes. Science 260, 1794-1796.

Malengreau, B., Lénat, J.-F., Bonneville, A., 1994. Cartographie et surveillance temporelle des anomalies de polarisation spontanee (PS) sur le Piton de la Fournaise: Cartography and temporal observation of self-potential (SP) anomalies at Piton de la Fournaise. Bull. Soc. Geol. Fr. 165 (3), 221-232.

Mazzuoli, R., Tortorici, L, Ventura, G., 1995. Oblique rifting in Salina, Lipari and Vulcano islands (Aeolian Islands, southern Italy). Terra Nova 7, 444-452.

Merle, O., Lénat, J.-F., 2003. Hybrid collapse mechanism at Piton de la Fournaise volcano, Reunion Island, Indian Ocean. J. Geophys. Res. 108 (B3), 2166.

Michel, S., Zlotnicki, J., 1998. Self-potential and magnetic surveying of La Fournaise Volcano (Reunion Island): correlations with faulting, fluid circulation, and eruption. J. Geophys. Res. 103, 17,845-17,857.

Montalto, A., 1994. Seismic signals in geothermal areas of active volcanism: a case study from "La Fossa", Vulcano (Italy). Bull. Volcanol. 56, 220-227.

Pribnow, D.F.C., Schütze, C., Hurter, S.J., Flechsig, C., Sass, J.H., 2003. Fluid flow in the resurgent dome of Long Valley Caldera: implications from thermal data and deep electrical sounding. J. Volcanol. Geotherm. Res. 127, 329-345.

Rabaute, A., Revil, A., Brosse, E., 2003. In situ mineralogy and permeability logs from downhole measurements. Application to a case study in clay-coated sandstone formations. J. Geophys. Res. 108, 2414. doi:10.1029/2002JB002178.

Ramsey, M.S., Fink, J.H, 1999. Estimating silicic lava vesicularity with thermal remote sensing: a new technique for volcanic mapping and monitoring. Bull. Volc. 61, 32-39.

Reid, M.E., Sisson, T.W., Brien, D.L., 2001. Volcano collapse promoted by hydrothermal alteration and edifice shape, Mount Rain ier, Washington. Geology 29 (9), 779-782.

Revil, A., Hermitte, D., Spangenberg, E., Cochémé, J.J., 2002. Electrical properties of zeolitized volcaniclastic materials. J. Geophys. Res. 107 (B8), 2168. doi:10.1029/ 2001JB000599. 
Revil, A., Finizola, A., Sortino, F., Ripepe, M, 2004. Geophysical investigations at Stromboli volcano, Italy: implications for ground water flow and paroxysmal activity. Geophys.J. Int. $157,426-440$.

Revil, A., Finizola, A., Piscitelli, S., Rizzo, E., Ricci, T., Crespy, A., Angeletti, B., Balasco, M Barde Cabusson, S., Bennati, L., Bolève, A., Byrdina, S., Carzaniga, N., Di Gangi, F., Morin, J., Perrone, A., Rossi, M., Roulleau, E., Suski, B., 2008. Inner structure of La Fossa di Vulcano (Vulcano Island, southern Tyrrhenian Sea, Italy) revealed by highresolution electric resistivity tomography coupled with self-potential, temperature, and $\mathrm{CO}_{2}$ diffuse degassing measurements. J. Geophys. Res. 113 (B07207) doi: $10.1029 / 2007$ JB005394.

Ricci, T., 2007. Studio del degassamento diffuso di $\mathrm{CO}_{2}$ e indagini geofisiche a finalita idrogeologica nei vulcani attivi di Stromboli e de La Fossa di Vulcano: variazioni temporali e loro significato vulcanologico, implicazioni strutturali, per il monitoraggio geochimico e per la pericolosità da gas. Phd Thesis, Università di Roma Tre.

Roberts, J.J., Lin, W., 1997. Electrical properties of partially saturated Topopah Spring tuff: water distribution as a function of saturation. Water Resour. Res. 33, 577-587.

Roche, O., Druit, T.H., Merle, 0., 2000. Experimental study of caldera formation. J. Geophys. Res. 105 (B1), 395-416.

Roche, O., van Wyk de Vries, B., Druitt, T.H., 2001. Sub-surface structures and collapse mechanisms of summit pit craters. J. Volcanol. Geotherm. Res. 105, 1-18.
Vallance, J.W., Scott, K.M., 1997. The Osceola Mudflow from Mont Rainier: sedimentology and hazard implications of a huge clay-rich debris flow. GSA Bull. 109 (2), 143-163.

Van Wyk de Vries, B., Kerle, N., Petley, D., 2000. Sector collapse forming at Casita volcano, Nicaragua. Geology 28 (2), 167-170.

Ventura, G., 1994. Tectonics, structural evolution and caldera formation on Vulcano Island (Aeolian Archipelago, southern Tyrrhenian Sea). J. Volcanol. Geotherm. Res. 60, 207-224.

Ventura, G, Vilardo, G., Milano, G., Pino, N.A., 1999. Relationships among crustal structure, volcanism and strike-slip tectonics in the Lipari-Vulcano Volcanic Complex (Aeolian Islands, Southern Tyrrhenian Sea, Italy. Phys. Earth Planet. Int. 116 (1-4), 31-52.

Voight, B., Elsworth, D., 1997. Failure of volcano slope. Géotechnique 47 (1), 1-31.

Walter, T.R., Troll, V.R., 2001. Formation of caldera periphery faults: an experimental study. Bull. Volcanol. 63, 191-203.

Wohletz, K., Heiken, G., 1992. In: Heiken, J.H. (Ed.), Volcanology and geothermal energy. InUniversity of California Press. $432 \mathrm{pp}$.

Zablocki, CJ., 1976. Mapping thermal anomalies on an active volcano by the selfpotential method, Kilauea, Hawaii. Proceedings, 2nd U.N. Symposium on the development and use of geothermal resources, San Francisco, California, May 1975, vol. 2, pp. 1299-1309. 